\title{
Who needs integration? Debating a central, yet increasingly contested concept in migration studies
}

Sawitri Saharso $0^{1,2}$

\author{
Correspondence: s.saharso@vu.nl \\ ${ }^{1}$ University of Humanistic Studies, \\ Utrecht, The Netherlands \\ 2Department of Sociology, VU \\ Amsterdam, Amsterdam, The \\ Netherlands
}

\begin{abstract}
Integration is a pivotal concept in migration studies. Yet, over time critiques have been formulated that question the very assumptions that the concept of integration rests on. Willem Schinkel, one of the major criticasters explains what is wrong with the concept. Is it that bad? Some of his discussants believe yes, but offer alternative conceptualizations as way out, whilst others believe the critique is unjustified and write in defense of integration.
\end{abstract}

Keywords: Integration, Integration critiques, Superdiversity, Integration as governance technique, Relational integration

Integration is a pivotal concept in migration studies. When migration researchers want to describe how immigrants find their way in the new country, the term they use is integration. The term commonly refers to both the socio-economic incorporation of immigrants in the host society, and to their socio-cultural adaptation to that society. ${ }^{1}$ Successful integration is usually considered as dependent on characteristics of the immigrant and of the receiving society. Since its inception the concept has been debated. One issue is for instance whether the analytical focus should be on the individual immigrant or on the group. Yet, over time critiques have been formulated that question the very assumptions that the concept of integration rests on. The concept aims to be descriptive, but in fact is normative, so claim some of its critics. It would suggest that immigrants' integration requires that they identify with the country of settlement, socialize with the majority population, preferably through intermarriage, and take over the norms and values of the majority population. Successful integration is defined and measured in these terms. The host population is thus the norm to which immigrants should aspire. Yet, who is this host population? Central to the idea of a host population is that it consists of a homogeneous group into which immigrants should integrate. Also, from a Black studies and anti-racist perspective the lens of integration is believed to put the problem wrongly, leading to a distortion of reality. Not immigrants and their (in)ability to integrate are the problem; the focus should be on racist structures of power and inequality in society. We should hence study not immigrants, but white society and constructions of whiteness, that create racial exclusions and patterns of inequality along racial lines, and how these intersect with other axis of inequality. Implied by the concept of integration is also the idea that immigrants integrate into a nation-state. This has led to an abundance of comparative studies on

(c) The Author(s). 2019 Open Access This article is distributed under the terms of the Creative Commons Attribution 4.0 International License (http://creativecommons.org/licenses/by/4.0/), which permits unrestricted use, distribution, and reproduction in any medium, provided you give appropriate credit to the original author(s) and the source, provide a link to the Creative Commons license, and indicate if changes were made. 
citizenship and national models of integration. Yet, a critique is that there are no national models, at least not as adequate descriptions of reality. National policies on integration are not so much the inescapable outcome of pre-existing historical national institutional models, but more often the result of more contingent political processes. National models are at best pre-conceived notions about how nations understand themselves, so runs the critique. Also, from a transnational perspective, the nation-state as the natural unit of analysis becomes rather problematic. When migrants lead transnational lives with affiliations in both, and perhaps more countries, it would seem no longer adequate to describe migrants' lives in terms of integration into the social life and culture of one specific nation state. These and other critiques on the concept of integration are worked out by Willem Schinkel (2018) in his key text. Integration theory suffers not merely from certain weaknesses, that could possibly be mended, but its foundational principles are unsound and harmful and the concept therefore should be discarded of as soon as possible, so he argues. Adrian Favell (2019) by and large agrees with Schinkel, and asks how, after the critique, we can move forward. He suggests that actually what is at stake are much broader issues around the production and reproduction of global inequalities. Leila Hadj-Abdou (2019) agrees with Schinkel that there is a lack of critical perspectives in the study of immigrant integration. Yet, rather than abandoning immigrant integration as a field of research she advocates conceptualizing it as a governance technique that can be critically studied. She uses the example of immigrant integration in cities as an illustration of such a critical perspective, that brings categories such as race and class back into the analysis. Fran Meissner (2019) too recognizes that migration research can contribute to harmful Othering and is often based on a problematic conception of society. Yet, she believes that Schinkel wrongly mixes up superdiversity with integration in his critique. Superdiversity is not just integration by another name, but rests on different theoretical premises and she explains why she considers it a useful tool for doing critical post-integration research. Lea Klarenbeek (2019) and Rinus Penninx (2019) write in defense of integration. Klarenbeek breaks a lance for a relational concept of integration that would overcome the problem that inherent to the concept of integration is the idea that it is always only one party, the immigrant, who has to integrate. Penninx believes Schinkel's representation of the state of the art in integration research is biased, overlooking contributions that do have sophisticated conceptualizations of society. Moreover, according to Penninx Schinkel conflates the use of integration concepts in integration policies with integration as it is used in integration research. And recognizing that there is a problematic policy-research nexus regarding integration, this does not necessarily prevent researchers to develop and apply their own independent, non-normative analytical concepts. Penninx illustrates this by explaining the analytical concept of the process of integration that he has developed together with Blanca Garcés-Mascareñas (2016). We conclude this debate, at least for now, as obviously it needs to be continued, by a rejoinder by Willem Schinkel (2019).

\section{Endnotes}

${ }^{1}$ Next to a binary distinction, one comes also across a threefold - Penninx and Garcés-Mascareñas (2016) include a legal-political level - or a fourfold distinction. Esser (1980) differentiates between culturation, rights, social interaction and identification. 
Competing interests

The author declares that she has no competing interests.

\section{Publisher's Note}

Springer Nature remains neutral with regard to jurisdictional claims in published maps and institutional affiliations.

Received: 30 August 2018 Accepted: 19 October 2018

Published online: 01 May 2019

\section{References}

Esser, H. (1980). Aspekte der wanderungssoziologie. Assimilation und integration von wanderern, ethnischen gruppen und minderheiten. Eine handlungstheoretische analyse [Aspects of migration sociology. Assimilation and integration of migrants, ethnic groups and minorities. An action theoretical analysis]. Neuwied/ Darmstadt: Hermann Luchterhand Verlag GmbH.

Favell, A. (2019). Integration: Twelve Propositions after Schinkel. Comparative Migration Studies, 7. https://doi.org/10.1186/ s40878-019-0125-7.

Hadj Abdou, L. (2019). Immigrant integration: the governance of ethno-cultural differences. Comparative Migration Studies, 7. https://doi.org/10.1186/s40878-019-0124-8.

Klarenbeek, L. (2019). Relational Integration: a Response to Willem Schinkel. Comparative Migration Studies, 7. https://doi.org/ 10.1186/s40878-019-0126-6.

Meissner, F. (2019). Of straw figures and multi-stakeholder monitoring - A response to Willem Schinkel. Comparative Migration Studies, 7. https://doi.org/10.1186/s40878-019-0121-y.

Penninx, R., \& Garcés-Mascareñas, B. (2016). The concept of integration as an analytical tool and as a policy concept. In B. Garcés-Mascareñas \& R. Penninx (Eds.), Integration Processes and Policies in Europe Contexts, Levels and Actors, (pp. 11-29). Springer, Cham. Retrieved from https://link.springer.com/book/10.1007/978-3-319-21674-4.

Penninx, R. (2019). Problems of and solutions for the study of Immigrant Integration. Comparative Migration Studies, 7. https:// doi.org/10.1186/s40878-019-0122-x.

Schinkel, W. (2018). Against 'immigrant integration': for an end to neocolonial knowledge production. Comparative Migration Studies, 6. https://doi.org/10.1186/s40878-018-0095-1.

Schinkel, W. (2019, in press). Migration Studies: an Imposition (Rejoinder). Comparative Migration Studies 7.

\section{Submit your manuscript to a SpringerOpen ${ }^{\circ}$ journal and benefit from:}

- Convenient online submission

- Rigorous peer review

Open access: articles freely available online

High visibility within the field

- Retaining the copyright to your article

Submit your next manuscript at $\boldsymbol{\nabla}$ springeropen.com 